ISSN: 2302-8556

E-Jurnal Akuntansi Universitas Udayana

Vol.24.3.September (2018):2414-2442

DOI: https://doi.org/10.24843/EJA.2018.v24.i03.p29

\title{
Persepsi Etis Auditor pada Kantor Akuntan Publik dan Akuntan Pendidik pada Praktik Manajemen Laba
}

\section{Putu Javani Sukma K ${ }^{1}$ \\ I Ketut Sujana ${ }^{2}$}

\author{
${ }^{1}$ Fakultas Ekonomi dan Bisnis Universitas Udayana, Bali, Indonesia \\ e-mail: putujavani13@gmail.com/Telp : 08978964220 \\ ${ }^{2}$ Fakultas Ekonomi dan Bisnis Universitas Udayana, Bali, Indonesia
}

\begin{abstract}
ABSTRAK
Penelitian ini bertujuan untuk mengetahui perbedaan persepsi etis auditor pada Kantor Akuntan Publik (KAP) dan akuntan pendidik pada praktik manajemen laba ditinjau dari jenis manipulasi operasional, jenis manipulasi akuntansi, arah manipulasi, materialitas dan kecendrungan manipulasi. Sampel dalam penelitian ini adalah auditor pada Kantor Akuntan Publik (KAP) sebanyak 41 orang dan akuntan pendidik sebanyak 30 orang, dengan jumlah keseluruhan sampel 71 orang. Pengambilan sampel dalam penelitian ini menggunakan metode purposive sampling dengan teknik analisis yang dilakukan dalam penelitian ini menggunakan teknik analisis Mann Whitney.Hasil penelitian menunjukan terdapat perbedaan persepsi etis antara auditor pada Kantor Akuntan Publik (KAP) dan akuntan pendidik pada praktik manajemen laba berdasarkan jenis manipulasi akuntansi dan arah manipulasi. Sedangkan tidak terdapat perbedaan persepsi etis antara auditor pada Kantor Akuntan Publik (KAP) dan akuntan pendidik pada praktik manajemen laba berdasarkan jenis manipulasi operasional, materialitas dan kecendrungan manipulasi.
\end{abstract}

Kata kunci: Persepsi, Etika, Manajemen Laba, Auditor, Akuntan

\begin{abstract}
The purpose of this research is to know the difference of auditor's ethical perception on public accounting firm and educator accountant on earnings management practice in terms of operational manipulation type, accounting manipulation, manipulation direction, materiality and manipulation tendency. Sample in this research is auditor at Public Accountant Office counted 41 people and accountant educator counted 30 people, with total sample 71 people. Sampling in this research using purposive sampling method with analysis technique which done in this research using Mann Whitney analysis technique. The result of the research shows that there is difference of ethical perception between auditor at Public Accountant Office and educator accountant on earnings management practice based on accounting manipulation type and manipulation direction. While there is no difference of ethical perception between auditor at Public Accountant Office and educator accountant on earnings management practice based on operational manipulation type, materiality and manipulation tendency.
\end{abstract}

Keywords: Perception, Ethics, Profit Management, Auditor, Accountant 
Putu Javani Sukma K dan I Ketut Sujana. Persepsi...

\section{PENDAHULUAN}

Informasi mengenai perusahaan sebagai dasar pertimbangan investor dalam pengambilan keputusan investasi. Salah satu bentuk informasi yang dibutuhkan oleh para pengambil keputusan terutama investor adalah laporan keuangan. Laporan keuangan merupakan hasil akhir dari dari proses akuntansi yang mengkomunikasikan informasi keuangan kepada pihak-pihak yang berkepentingan. Informasi laba dalam laporan keuangan merupakan salah satu yang menjadi perhatian utama untuk memperkirakan kinerja atau pertanggungjawaban manajemen dan dapat membantu pemilik atau investor memperkirakan kemampuan perusahaan dalam menghasilkan laba di masa yang akan datang. Kinerja manajemen perusahaan tercermin pada laba yang terkandung dalam laporan keuangan, sehingga informasi laba merupakan informasi yang penting sebagai dasar pengambilan keputusan investasi. Menurut Agnes (2001), manajemen laba adalah suatu tindakan yang mendorong perilaku menyimpang dari seorang manajer dalam memberikan informasi, hal ini disebabkan oleh kecenderungan informasi laba yang didasari oleh manajemen tersebut.

Tindakan suatu manajemen dalam memaksimalkan nilai suatu perusahaan dapat dilakukan dengan cara memilih kebijakan akuntansi yang sudah ada (Scott, 2000). Rozenzweig dan Fischer (1995) mengemukakan, dalam menyajikan laporan seorang manajer dapat memaksimumkan dan meminimumkan laba suatu periode tertentu pada perusahaan yang ditanggung, tanpa harus menaikkan atau menurunkan profit usaha tersebut. Seorang manajer melakukan pertimbangan (judgement) saat membuat laporan keuangan dalam memperoleh suatu keuntungan yang nantinya digunakan 
ISSN: 2302-8556

E-Jurnal Akuntansi Universitas Udayana

Vol.24.3.September (2018):2414-2442

untuk membuat perjanjian kepada stakeholders, yang didasari dari memanipulasi besaran laba perusahaan tersebut (Wahlen dan Healy, 1999).

Manajemen laba merupakan fenomena umum yang masih terjadi di perusahaan. Praktik yang dilakukan untuk mempengaruhi angka laba dapat terjadi secara legal maupun tidak legal. Praktik legal dalam manajemen laba berarti usaha untuk mempengaruhi angka laba tidak bertentangan dengan aturan pelaporan keuangan dalam Prinsip-prinsip Akuntansi Berterima Umum (PABU), khususnya dalam Standar Akuntansi, yaitu dengan cara memanfaatkan peluang untuk melakukan perubahan metode akuntansi, dan menggeser periode pendapatan atau biaya. Donald Cressey (1950) dalam Suradi (2012) manajemen laba yang dilakukan secara ilegal (financial fraud), dilakukan dengan cara-cara yang melanggar PABU, misalnya dengan cara melaporkan transaksi-transaksi pendapatan atau biaya secara fiktif dengan cara menambah (mark up) atau mengurangi (mark down) nilai transaksi atau dapat pula dengan tidak melaporkan sejumlah transaksi sehingga akan menghasilkan laba pada nilai atau tingkat tertentu yang diinginkan.Contoh kasus manajemen laba yang pernah terjadi di Indonesia adalah manajemen laba pada PT. Kimia Farma Tbk. Pihak manajemen PT.Kimia Farma melakukan penggelembungan (mark up) laba pada laporan keuangan tahun 2001 sebesar Rp 32,6 milyar. Berdasarkan penyelidikan Bapepam disebutkan bahwa KAP yang mengaudit laporan keuangan PT. Kimia Farma telah mengikuti standar audit yang berlaku, namun gagal mendeteksi kecurangan tersebut. Selain itu, Kantor Akuntan Publik (KAP) tersebut juga tidak 
Putu Javani Sukma K dan I Ketut Sujana. Persepsi...

terbukti membantu manajemen melakukan kecurangan tersebut (Kompas, 21 November 2002).

Adakalanya praktik manajemen laba yang dilakukan oleh manajemen menyebabkan perusahaan tidak mampu mempertahankan kinerjanya dalam jangka panjang.Sulistyanto dan Wibisono (2003) dalam penelitiannya berhasil membuktikan bahwa terjadi penurunan kinerja keuangan dan kinerja saham yang disebabkan oleh sikap oportunis manajer. Tindakan manajemen laba juga menyebabkan pengungkapan informasi mengenai laba menjadi menyesatkan sehingga akan mengakibatkan terjadinya kesalahan dalam pengambilan keputusan oleh pihak-pihak yang berkepentingan dengan perusahaan, khususnya pihak eksternal. Manajemen laba menjadi suatu hal yang merugikan investor, karena investor tidak akan memperoleh informasi yang akurat mengenai laba untuk mengevaluasi tingkat pengembalian portofolionya. Selain itu, tindakan manajer melakukan manajemen laba dapat dikategorikan sebagai suatu tindakan penipuan yang tidak etis, siapapun yang menggunakan laporan keuangan yang mengandung unsur manajemen laba rawan terhadap misinterpretasi, manipulasi ataupun penipuan yang disengaja (Bruns dan Merchant, 1990).

Teknik yang biasanya digunakan untuk menilai baik buruknya manajemen laba tergantung pemenejemenan laba tersebut dan memotivasinya. Akhir-akhir ini pemenejeman laba menjadi fenomena umum yang dapat terjadi dalam kondisi legal ataupun non-legal (ilegal). Praktik legal dapat diartikan sebagai usaha dalam mempengaruhi manajemen laba sesuai dengan peraturan pelaporan keuangan Prinsip 
ISSN: 2302-8556

E-Jurnal Akuntansi Universitas Udayana

Vol.24.3.September (2018):2414-2442

Akuntansi Berterima Umum, didalamnya terdapat standar akuntansi melalui pemanfaatan suatu peluang yang dapat membuahkan estimasi akuntansi tersebut, merubah periode pendapatan biaya dan mengubah metode akuntansi. Praktik secara illegal (financial fraud), dalam Pedoman Akuntansi Berterima Umum dilarang membuat pemenejemenan laba secara illegal, hal tersebut dapat diantisipasi dengan cara pelaporan transaksi profit suatu perusahaan secara fiktif, yang nantinya dapat memeroleh laba yang dikehendaki (pondokskripsi.wordpress.com).

John dan Subramnayam (2013: 130), akuntansi akrual yang nyata biasanya jarang di pakai dalam manajemen laba. Kredibilita informasi akuntansi dapat diragukan jika informasi manajemen laba tidak dipublikasikan dalam pers. Yulianto (2010), kebijakan akuntansi konservatif memerlukan biaya modal lebih rendah dari perusahaan yang menerapkan kebijakan akuntansi agresif, hal tesebut memiliki manfaat informasi pengambilan keputusan dalam pemenejemanan laba.

Meckling dan Jensen (1986) menyebutkan perusahaan sebagai penghubung antara agen dan principal, dimana perusahaan menaungi hubungan kontrak antara individu-individu di dalam perusahaan tersebut.Pemegang saham atau pemilik perusahaan berperan sebagai principal sedangkan manajer berfungsi sebagai agen, manajer diberikan tugas oleh principal untuk memenuhi kepentingan yang menguntungkan bagi principal.Manajemen laba timbul sebagai dampak persoalan keagenan, yaitu ketidakselarasan kepentingan antara manajer dan pemilik perusahaan yang dikarenakan adanya asimetri informasi.Asimetri informasi adalah suatu kondisi dimana adanya tidak keseimbangan dalam perolehan informasi antara manajemen dan 
pemegang saham dimana manajemen memiliki informasi yang lebih dibanding dengan pihak eksternal.

Terdapat beberapa faktor yang menjadi alasan mengapa perusahaan atau pihak manajemen melakukan manajemen laba. Keberadaan peluang ini dikarenakan dalam Prinsip Akuntansi Berterima Umum (PABU) atau Generally Accepted Accounting Principles (GAAP) itu sendiri memberikan kebebasan kepada pembuat laporan keuangan untuk memilih metode atau kebijakan yang dianggap paling tepat untuk diterapkan pada laporan keuangan pada satu periode tertentu. Kebebasan dan fleksibilitas dalam memilih satu dari berbagai alternative metode yang dapat digunakan dalam PABU akan menyebabkan manajemen untuk memilih menerapkan metode yang dapat mendukung kepentingannya.

Kajian dalam filsafat tentang moralitas dan moral dalam perkembangannya memakai etika dalam penyelidikannya atau pengkajiannya yang dilakukan secara sistematis (Ghozali Imam, 1997). Pendidikan etika memiliki tujuan untuk membuat seorang mahasiswa mampu menyadari dimensi etik serta dimensi sosial didalam setiap pembuatan dan keputusan bisnis mereka suatu hari kelak, dan bukannya hanya untuk mengubah cara pandang seorang mahasiswa mengenai apa dan bagaimana tindakan yang seharusnya dapat mereka lakukan pada suatu situasi tertentu (Mager danWynd dalam Donleavydan McDonald, 1995). Sedangkan menurut Imam Ghozali (1997) dalam wadah terciptanya suatu perilaku etis yang sering terlupakan didalam praktek sistematis pendidikan tinggi kita, dampaknya bukanlah sesuatu hal yang aneh bilamana kepekaanrasa, kepribadian,hati, dan nilai ketidak seimbangandengan satu 
ISSN: 2302-8556

E-Jurnal Akuntansi Universitas Udayana

Vol.24.3.September (2018):2414-2442

unsur ilmu pengetahuan serta profesionalisme. Konsekuensi logis dalam hal ini adalah terciptanya suatu split personality didalam diri para seorang lulusan perguruan tinggi. Praktik manajemen laba merupakan salah satu bentuk perhatian pada masalah etika. Oleh karena itu, hal ini sangat perlu diperkenalkan untuk pengembangan kurikulum, karena praktik manajemen laba dinilai bersifat ambigu secara etis (Fischer dan Rosenzweig (1995). Fatt (1995) menyatakan pendekatan kasus dalam pendidikan etika merupakan cara efektif untuk menyadarkan mahasiswa pada masalah-masalah dilematis secara etis dan untuk melatih proses pengambilan keputusan dalam situasi tertentu.

Mencermati hal tersebut di atas perlu kiranya untuk mengetahui bagaimana pandangan auditor pada Kantor Akuntan Publik (KAP) dan akuntan pendidik terhadap persoalan etika, yang dalam hal ini mengacu pada praktik manajemen laba yang mungkin sudah ataupun yang akan mereka hadapi. Penelitian ini dilakukan terhadap auditor pada KAP karena auditor di sini berperan sebagai praktisi yang secara langsung melihat/menghadapi kejadian praktik manajemen laba di dunia kerja. Selain itu, karena auditor juga perlu untuk memahami manajemen laba untuk mendapatkan pemahaman yang lebih atas praktik ini serta menjadi pertimbangan dalam memberi nasehat atau evaluasi metode akuntansi untuk pelaporan akuntansi. Akuntan pendidik juga dipilih sebagai sampel karena akuntan pendidik menjadi penghubung antara mahasiswa dengan dunia kerja. Selain itu, akuntan pendidik juga tidak terlepas dari aktivitas bisnis dan pendidikan akan memberikan informasi secara langsung kepada mahasiswa mengenai informasi persoalan etika dalam bisnis. Etis 
atau etika sebenarnya merupakan dalam sebuah proses suatu penentuan yang begitu kompleks tentang apa yang memang harus dilakukan seseorang didalam situasi tertentu. Pada argumen ini yang didasarkan dalam ketidak setujuannya terhadap pengertian etika yang dianggap sebagai suatu pernyataan yang benar-salah atau baik-buruk.

Pratley (1997) mendefinisikan etika sebagai suatu cabang ilmu filsafat yang tujuannya mempelajari perilaku, baik moral maupun immoral dengan tujuan membuat pertimbangan yang cukup beralasan dan akhirnya sampai pada rekomendasi. Etika sebagai suatu cabang ilmu pengetahuan (filsafat), memberikan pemahaman kepada manusia untuk selalu berpikir positif, rasionil, berdasarkan hati dan moralitas sebagai alternatif untuk menelaah sebelum mengambil suatu tindakan atau keputusan. Hal ini didasari atas dinamika kehidupan manusia yang cenderung berubah-ubah sehingga dapat mengalami pergeseran nilai-nilai moralitas manusia dan pada akhirnya lupa tentang etika. Siagian (1996) menyebutkan, ada empat alasan mengapa mempelajari etika : (1) Etika dapat mendorong timbulnya suatu naluri moralitas serta mengilhami manusia untuk bersama-sama mencari, menemukan, dan menerapkan nilai-nilai hidup yang baik, (2) dinamika didalam kehidupan seorang manusia akan menyebabkan perubahan nilai-nilai moral dan sehingga perlu dilakukan analisa serta tinjauan ulang, (3) etika adalah pola perilaku yang mendasari kesepakatan suatu nilai sehingga kehidupan dapat harmonis dan tercapai, (4) etika memandu seorang manusia didalam memilih berbagai suatu keputusan yang dihadapi didalam kehidupan.

Martindan Nurmala (2007) dalam penelitiannyaberpersepsi etis mahasiswa akuntansi kepada praktik earnings management dan ditinjau pada faktor jenis 
ISSN: 2302-8556

E-Jurnal Akuntansi Universitas Udayana

Vol.24.3.September (2018):2414-2442

manipulasi, materialitas, arah manipulasi, serta kecenderungan dari manajemen laba itu didalam perspektif gender. Dalam penelitian ini yang menghasilkan suatu kesimpulan tidak jauh berbeda terhadap penelitian dari Clikeman et.al.(2000), yaitu dalam menguji faktor-faktor yang mempengaruhi persepsi penerimaan terhadap etika dari manajemen laba dengan sampel mahasiswa dan mahasiswi akuntansi. Keempat faktor tersebut adalah jenis, arah, materialitas dan kecenderungan dari manajemen laba. Hasil dari penelitian ini menunjukkan bahwa tidak terdapat perbedaan persepsi yang signifikan antara mahasiswa dan mahasiswi antar semua faktor.

Yulaika (2011), dalam penelitiannya berjudul Persepsi Etis Pelaku Bisnis dan Mahasiswa Akuntansi Terhadap Praktik Manajemen Laba. Hasil penelitiannya adalah adanya pebedaan yang signifikan antara persepsi seorang pelaku bisnis serta mahasiswa akuntansi terhadap kinerja praktik manajemen laba.Seorang mahasiswa akuntansi dapat memiliki kecenderungan yang tidak dapat menerima suatu praktik manajemen laba dari sisi etika jika dibandingkan dengan pelaku bisnis. Sebuah faktor yang mempunyai pengaruh paling signifikan pada persepsi etis merupaan faktor arah manajemen laba, yaitu dapat menunda pengeluaran akrual yang akan meningkatkan laba. Kedua peneliti diatas pada intinya mendorong kepada kita semua untuk selalu menggunakan hati nurani dalam menganalisis berbagai masalah agar nantinya mampu menghasilkan keputusan yang memberikan kesejukan, kenyamanan dan harmonis kepada semua pihak.

Berdasarkan teori, tinjauan literatur dan hasil penelitian sebelumnya yang dipaparkan, maka dapat dirumuskan hipotesis sebagai berikut. 
$\mathrm{H}_{1}$ : Tidak terdapat perbedaan persepsi ditinjau dari jenis manipulasi operasional

Marti dan Nurmala (2007) dalam penelitiannya menyimpulkan bahwa tidak terdapat perbedaan yang signifikan dari keempat faktor yang diteliti, keempat faktor tersebut adalah kecenderungan manipulasi, arah manipulasi, jenis manipulasi dan materialitas. Kesimpulan ini juga tidak jauh berbeda dengan dari penelitian yang dilakukan Clikeman et.al (2000).

$\mathrm{H}_{2}$ : Terdapat perbedaan persepsi ditinjau dari jenis manipulasi akuntansi

Pratiwi (2011) mengungkapkan bahwa terdapat perbedaan persepsi etis yang nyata terhadap manajemen laba yang dilakukan melalui manipulasi keputusan operasional. Akuntan pendidik lebih mengedepankan profesi dan logika dalam memahami konsep jenis manipulasi akuntansi pada praktik manajemen laba. Sedangkan auditor pada KAP mengedepankan profesionalitas dalam setiap pengambilan keputusan berdasarkan hati nurani dan etika untuk melaksanakan prinsip akuntansi yang berlaku umum, akuntan pendidik berpegang pada profesi dan menekankan pada pemahaman akan prinsip akuntansi yang berlaku.

Sedangkan auditor pada KAP mengedepankan profesionalitas dalam setiap pengambilan keputusan didasari dengan etika dan hati nurani dalam menerapkan praktik manajemen laba. Perbedaan ini juga dapat disebabkan oleh lingkungan pekerjaan, pengalaman kerja dan profesionalitas. Kesimpulan ini sesuai dengan peneliti sebelumnya, Inggarwati (2010).

$\mathrm{H}_{3}$ : Terdapat perbedaan persepsi ditinjau dari arah manipulasi 
ISSN: 2302-8556

E-Jurnal Akuntansi Universitas Udayana

Vol.24.3.September (2018):2414-2442

Pratiwi (2011) juga mengungkapkan bahwa terdapat perbedaan persepsi etis auditor pada KAP dan akuntan pendidik di tinjau dari arah manipulasi. Perbedaan ini juga dapat disebabkan oleh lingkungan pekerjaan, pengalaman kerja dan profesionalitas.

$\mathrm{H}_{4}$ : Tidak terdapat perbedaan persepsi ditinjau dari materialitas.

Marti dan Nurmala (2007) dalam penelitiannya menyimpulkan bahwa tidak terdapat perbedaan yang signifikan dari keempat faktor yang diteliti, keempat faktor tersebut adalah kecenderungan manipulasi, arah manipulasi, jenis manipulasi dan materialitas. Kesimpulan ini juga tidak jauh berbeda dengan dari penelitian yang dilakukan Clikeman et.al (2000).

$\mathrm{H}_{5}$ : Tidak terdapat perbedaan persepsi ditinjau dari kecenderungan manipulasi.

\section{METODE PENELITIAN}

Penelitian ini dilakukan pada KAP di Provinsi Bali yang terdaftar dalam direktori Kantor Akuntan Publik dan Akuntan Publik tahun 2016. Alasan dipilihnya lokasi ini karena KAP yang terdaftar di dalam direktori telah memperoleh izin dari Menteri Keuangan RI sebagai wadah akuntan publik dalam melaksanakan pekerjaannya dan mudah diketahui serta nama alamatnya, sesuai Tabel 1.

Tabel 1.

Daftar Kantor Akuntan Publik di Provinsi Bali tahun 2016

\begin{tabular}{cll}
\hline No. & \multicolumn{1}{c}{ Nama Kantor Akuntan Publik } & \multicolumn{1}{c}{ Alamat } \\
\hline 1 & KAP I Wayan Ramantha & Jl. Rampai No.1 A Lantai 3, Denpasar \\
2 & KAP Budhananda Munidewi & Jl. Tk. Irawadi \\
3 & KAP Drs. Ketut Budiartha, Msi & Jl. Gunung Agung, Denpasar Barat \\
4 & KAP Drs. Ketut Muliartha RM \& Rekan & $\begin{array}{l}\text { Gedung Guna Teknosa lantai 2, Jl. Drupadi } \\
\text { No. 25 Renon, Denpasar }\end{array}$ \\
5 & KAP Drs. Sri Marmo Djogosarkoro \& & Jl. Gunung Muria No. 4 Monang-maning,
\end{tabular}


Rekan

6 KAP Drs. Ida Bagus Djagera

7 KAP. Drs. Johan Malonda, Astika \& Rekan (Cab)

8 KAP K. Gunarsa

9

KAP Drs. Tasnim Ali Widjanarko \& Rekan (Cab)

10 KAP Drs. I Made Oka \& Rekan

11 KAP Rama Wendra (Cab)

12 KAP Drs. Wayan Sunasdyana
Denpasar

Jl. Hasanuddin No.1 Denpasar

Jl. Muding Indah I No. 5 Kuta Utara, Kerobokan, Denpasar

Jl. Tukad Pakerisan No.116 A, Panjer, Denpasar

J1. Kepundung No.12 Denpasar

J1. Werkudara No.5 Denpasar

Jl. Jendral Sudirman Denpasar

Jl. Pura Demak I gang I B no.8 Teuku Umar Barat, Denpasar

Sumber : Direktori Kantor Akuntan Publik dan Akuntan Publik, 2016

Lokasi penelitian yang kedua di Fakultas Ekonomi dan Bisnis Universitas Udayana. Alasan dipilihnya lokasi ini karena penulis menempuh pendidikan di Fakultas Ekonomi dan Bisnis Universitas Udayana.Objek dalam penelitian ini adalah persepsi etis auditor pada Kantor Akuntan Publik dan Akuntan Pendidik pada praktik manajemen laba. Variabel-variabel yang digunakan dalam penelitian ini adalah variabel yang berkaitan dengan praktik manajemen laba, yaitu Jenis manipulasi (type of manipulation / TYPE), Arah manipulasi (direction of manipulation / DIRECT), Materialitas (materiality / MATERIAL), dan Kecenderungan manipulasi (intention / INTENT). Jenis manipulasi (type of manipulation / TYPE) adalah upaya manajemen laba dengan mempergunakan 2 jenis tipe manipulasi, pertama jenis manipulasi operasional yaitu dengan cara penentuan suatu transaksi pada akhir tahun untuk memindahkan suatu pendapatan serta biaya didalam periode pelaporan yang diinginkan. Arah manipulasi (direction of manipulation/ DIRECT) merupakan suatu upaya untuk meningkatkan atau menurunkan jumlah laba dengan cara mempercepat pengeluaran akrual. Sebagai pertimbangan untuk membuat pernyataan kuesioner soal no 3 (Pratiwi, 2011). Materialitas (materiality / MATERIAL) adalah upaya 
ISSN: 2302-8556

E-Jurnal Akuntansi Universitas Udayana

Vol.24.3.September (2018):2414-2442

melakukan manajemen laba dalam jumlah yang dianggap material. Sebagai pertimbangan untuk membuat pernyataan kuesioner dari soal no 12 dan 13 (Pratiwi, 2011). Kecenderungan manipulasi (intention / INTENT) adalah tujuan/maksud tertentu manajemen dalam melakukan praktik manajemen laba. Sebagai pertimbangan untuk membuat pernyataan kuesioner soal no 10 dan 11 (Pratiwi, 2011).

Data kualitatif, yaitu data yang dinyatakan dalam bentuk kata, kalimat, dan skema. Data kualitatif dalam penelitian ini berupa nama-nama Kantor Akuntan Publik di Provinsi Bali, Fakultas Ekonomi dan Bisnis Universitas Udayana. Data kuantitatif, yaitu data yang dinyatakan dalam bentuk angka, dan merupakan data yang berskala ukuran inverval rasio (Rahyuda, 2004:75). Data kuantitatif dalam penelitian ini adalah jumlah responden penelitian dan data kualitatif yang diangkakan dengan bantuan skala Likert, yaitu dengan memberikan respon terhadap pernyataan dengan memiliki salah satu dari lima pilihan berjenjang. Namun, agar tidak terjadi bias dalam responden memberikan jawaban, maka kuesioner dalam penelitian inidibuat dengan menggunakan empat alternative jawaban dengan alasan (Moeljono, 2002 dalam Melaning, 2010).

Sumber data yang digunakan dalam penelitian ini meliputi data primer dan data sekunder.Data primer diperoleh dari kuesioner/daftar pertanyaan yang telah tersrtuktur dengan tujuan untuk mengumpulkan informasi dari para responden.Untuk mendapatkan data ini, kuesioner didistribusikan kepada responden yaitu auditor pada Kantor Akuntan Publik dan Akuntan Pendidik.Data sekunder dalam penelitian ini 
berupa data yang diolah dan diperoleh oleh peneliti dari pihak-pihak yang berkaitan dengan permasalahan yang diteliti seperti nama-nama Kantor Akuntan Publik, data jumlah akuntan pendidik Fakultas Ekonomi dan Bisnis Universitas Udayana.

Alasan dipilihnya sampel auditor pada Kantor Akuntan Publik karena auditor merupakan praktisi yang telah memperoleh keterampilan khusus, yaitu keterampilan intelektual, interpersonal, dan komunikasi (Swardjono, 1999 dalam Wahyudin, 2003).Profesi auditor independen atau akuntan publik didalam aktivitasnya tidak dapat dipisahkan dengan kegiatan bisnis yang diantara lebih mengetahui fenomena mengenai praktik manajemen laba. Selain itu, auditor juga perlu untuk memahami manajemen laba untuk mendapatkan pemahaman yang lebih atas praktik ini serta menjadi bahan pertimbangan dalam memberi suatu nasehat serta evaluasi metode akuntansi untuk laporan akuntansi. Akuntan pendidik dipilih sebagai sampel karena akuntan pendidik menjadi penghubung antara mahasiswa akuntansi dengan keadaan dunia kerja. Selain itu, akuntan pendidik yang tidak terlepas dari aktivitas bisnis dan pendidikan akan memberikan informasi secara langsung kepada mahasiswa akuntansi mengenai persoalan-persoalan etika dalam bisnis.

Populasi penelitian ini adalah auditor independen yang bekerja pada kantor akuntan publik yang terdaftar dalam Direktori Akuntan Publik dan Akuntan Publik tahun 2016 dan akuntan pendidik di Fakultas Ekonomi dan Bisnis Universitas Udayana. Metode penentuan sampel menggunakan non probability sampling dengan teknik penentuan sampel yang digunakan dalam penelitian ini adalah purposive sampling, yaitu teknik penentuan sampel dengan pertimbangan tertentu, dimana 
ISSN: 2302-8556

E-Jurnal Akuntansi Universitas Udayana

Vol.24.3.September (2018):2414-2442

anggota-anggota sampel akan dipilih sedemikian rupa sehingga sampel yang dibentuk tersebut dapat mewakili sifat-sifat populasi (Sugiyono, 2009).

Penelitian ini menggunakan survey method, data yang digunakan dalam penelitian ini diperoleh melalui teknik kuesioner dan dokumentasi. Kuesioner merupakan metode yang digunakan untuk memperoleh data primer yang relevan dengan objek penelitian yang berupa serangkaian pertanyaan atau pernyataan tertulis yang diajukan kepada responden untuk dijawab (Sugiyono, 2009). Kuesioner didistribusikan secara langsung kepada responden (auditor pada KAP dan akuntan pendidik).

Dokumentasi merupakan teknik pengumpulan data dengan mencatat, mengutip, serta mengumpulkan data dari dokumen perusahaan/instansi tertentu (Maleong, 2006 dalam Tanuari, 2008) yaitu data tentang Kantor Akuntan Publik (KAP) yang diperoleh dari Direktori Kantor Akuntan Publik dan Akuntan Publik tahun 2016, jumlah akuntan pendidik (dosen/pengajar) yang diperoleh dari Pusat Informasi Fakultas Ekonomi dan Bisnis Universitas Udayana.

Penelitian ini untuk mengkaji hipotesis digunakan alat uji statistic nonparametrik. Teknik analisis yang digunakan untuk mengetahui signifikansi adanya perbedaan serta dapat ditunjukkannya urutan ranking skor rata-rata penerimaan etika pada 2 kelompok sampel yang berbeda sebagaimana yang dihipotesiskan pada hipotesis adalah Mann-Whitney Test (Siegel Sidney, 1985, dalam Pratiwi, 2011: 39). Adapun kriterianya adalah sebagai berikut.

$\mathrm{H}_{0}$ : tidak dapat ditolak apabila Asymp sig. $>\alpha=0.05$ 
$\mathrm{H}_{\mathrm{a}}$ : diterima apabila Asymp sig. $\leq \alpha=0.05$

\section{HASIL DAN PEMBAHASAN}

Sugiyono (2007) menyatakan bahwa hasil penelitian dikatakan valid apabila terdapat kesamaan antara dua data yang terkumpul dengan data yang sesungguhnya terjadi pada objek yang diteliti.Uji validitas digunakan dalam penelitian ini untuk mengukur sejauh mana alat ukur yang berupa 13 pernyataan kuesioner dapat dengan cermat mengukur tentang praktik manajemen laba.Untuk menguji validitas dalam penelitian ini digunakan program SPSS for Windows. Jika koefisien korelasi positif dan lebih besar dari $r$ kritis (0.30) maka instrumen penelitian tersebut dikatakan valid.Hasil uji validitas untuk setiap item pernyataan dari persepsi responden pada praktik manajemen laba dapat dilihat pada Tabel 2, Tabel 3, Tabel 4 dan Tabel 5.

Tabel 2.

Hasil Uji Validitas Tiap Item Pernyataan dari Persepsi Responden berdasarkan Jenis Manipulasi - Operasional

\begin{tabular}{lcc}
\hline Pernyataan & Koefisien Korelasi Pearson & Keputusan \\
\hline Pernyataan 1 & 0,782 & Valid \\
Pernyataan 2 & 0,752 & Valid \\
Pernyataan 3 & 0,719 & Valid \\
Pernyataan 5 & 0,779 & Valid \\
Pernyataan 6 & 0,779 & Valid \\
Pernyataan 7 & 0,647 & Valid \\
\hline
\end{tabular}

Sumber : Data diolah, 2017

\section{Tabel 3.}

Hasil Uji Validitas Tiap Item Pernyataan dari Persepsi Responden berdasarkan Jenis Manipulasi - Akuntansi

\begin{tabular}{ccc}
\hline Pernyataan & Koefisien Korelasi Pearson & Keputusan \\
\hline Pernyataan 4 & 0,698 & Valid
\end{tabular}


ISSN: 2302-8556

E-Jurnal Akuntansi Universitas Udayana

Vol.24.3.September (2018):2414-2442

\begin{tabular}{lll} 
Pernyataan 8 & 0,474 & Valid \\
Pernyataan 9 & 0,583 & Valid \\
Pernyataan 10 & 0,747 & Valid \\
Pernyataan 11 & 0,688 & Valid \\
Pernyataan 13 & 0,680 & Valid \\
\hline
\end{tabular}

Sumber : Data diolah, 2017

Tabel 4.

Hasil Uji Validitas Tiap Item Pernyataan dari Persepsi Responden berdasarkan Materialitas

\begin{tabular}{ccc}
\hline Pernyataan & Koefisien Korelasi Pearson & Keputusan \\
\hline Pernyataan 12 & 0,819 & Valid \\
Pernyataan 13 & 0,894 & Valid \\
\hline
\end{tabular}

Sumber : Data diolah, 2017

Tabel 5.

Hasil Uji Validitas Tiap Item Pernyataan dari Persepsi Responden berdasarkan Kecenderungan Manipulasi

\begin{tabular}{ccc}
\hline Pernyataan & Koefisien Korelasi Pearson & Keputusan \\
\hline Pernyataan 10 & 0,889 & Valid \\
Pernyataan 11 & 0,838 & Valid \\
\hline Sumber : Data diolah, 2017 & &
\end{tabular}

Berdasarkan hasil uji Validitas pada Tabel 2, Tabel 3, Tabel 4 dan Tabel 5, diketahui bahwa koefisien korelasi hasil uji validitas tiap item pernyataan dari persepsi responden pada jenis manipulasi operasional, akuntansi, materialitas dan kecenderungan manipulasi lebih besar dari 0.3 , sehingga dapat disimpulkan bahwa tiap item pernyataan dari persepsi responden dalam penelitian ini adalah valid sehingga dapat digunakan dalam uji selanjutnya.

Pengujian reliabilitas atau keandalan instrumen menunjukkan sejauh mana suatu pengukuran kembali terhadap gejala yang sama (Sugiyono, 2009). Instrumen yang reliable adalah instrumen yang digunakan beberapa kali untuk mengukur objek yang sama yang akan menghasilkan data atau jawaban yang sama pula. Untuk menguji reliabilitas pada penelitian ini digunakan teknik analisis data dengan cronbach's alpha dengan bantuan program SPSS for Windows. Instrumen dapat 
dikatakan handal (reliable) bila memiliki koefisien cronbach alpha lebih besar dari 0.60 (Ghozali, 2006). Hasil uji reliabilitas instrumen ditunjukkan pada Tabel 4.12 berikut.

Tabel 6.

Hasil Uji Reliabilitas

\begin{tabular}{lcc}
\hline \multicolumn{1}{c}{ Variabel } & Koefisien Cronbach's Alpha & Interpretasi \\
\hline Jenis Manipulasi - Operasional & 0,836 & Reliabel \\
Jenis Manipulasi - Akuntansi & 0,721 & Reliabel \\
Materialitas & 0,631 & Reliabel \\
Kecenderungan Manipulasi & 0,656 & Reliabel \\
\hline Sumber $:$ Data dion 2017
\end{tabular}

Sumber : Data diolah, 2017

Berdasarkan Tabel 6 diketahui bahwa koefisien Cronbach Alpha hasil uji reliabilitas pernyataan responden lebih besar dari 0.6 sehingga dapat disimpulkan bahwa instrumen penelitian yang digunakan dalam penelitian ini adalah reliabel. Dalam penelitian ini untuk mengkaji hipotesis digunakan alat uji statistic non-parametrik. Teknik analisis yang digunakan untuk mengetahui signifikansi adanya perbedaan serta dapat ditunjukkannya urutan ranking skor rata-rata penerimaan etika pada 2 kelompok sampel yang berbeda sebagaimana yang dihipotesiskan pada hipotesis adalah Mann-Whitney Test (Siegel Sidney, 1985). Hasil pengujian hipotesis berdasarkan persepsi responden terhadap masingmasing variabel yang digunakan dalam penelitian ini dapat ditunjukkan pada Tabel 4.13.

Tabel 7.

Hasil Uji Mann Whitney per-variabel pada Akuntan Publik dan Akuntan Pendidik

\begin{tabular}{lccc}
\hline \multirow{1}{*}{ Variabel } & \multirow{2}{*}{$\begin{array}{c}\text { Asymp. Sig } \\
\text { (2-Tailed) }\end{array}$} & Auditor pada KAP & $\begin{array}{c}\text { Akuntan } \\
\text { Pendidik }\end{array}$ \\
\cline { 3 - 4 } & 0,086 & 32,43 & 40,88 \\
Manipulasi - Operasional & 0,038 & 31,67 & 41,92 \\
Manipulasi - Akuntansi & 0,038 & 31,74 & 41,82 \\
Arah Manipulasi & 0,191 & 33,50 & 39,42 \\
Materialitas & 0,472 & 34,52 & 38,02 \\
Kecenderungan Manipulasi & & &
\end{tabular}


ISSN: 2302-8556

E-Jurnal Akuntansi Universitas Udayana

Vol.24.3.September (2018):2414-2442

Metode uji yang digunakan untuk menjawab permasalahan pada hipotesis 1 adalah uji Mann Whitney. Kaidah pengambilan keputusan yang digunakan dalam metode ini adalah asymp sig. $\leq \alpha$, maka $\mathrm{H}_{0}$ ditolak sedangkan bila asymp sig. $>\alpha$ maka $\mathrm{H}_{0}$ diterima, dimana taraf nyata yang digunakan $\alpha=0,05$.Berdasarkan hasil uji hipotesis pada Tabel 7 diperoleh nilai asymp sig.(2-tailed) untuk variabel Manipulasi - Operasional sebesar 0,086 lebih besar dari 0,05 dengan nilai mean rank pada auditor pada KAP 32,43 dan pada akuntan pendidik 40,88, hal ini menunjukkan bahwa tidak ada perbedaan yang signifikan persepsi responden tentang manipulasi operasional baik pada auditor pada KAP maupun pada akuntan pendidik.

Metode uji yang digunakan untuk menjawab permasalahan pada hipotesis 2 adalah uji Mann Whitney. Kaidah pengambilan keputusan yang digunakan dalam metode ini adalah bila asymp sig. $\leq \alpha$, maka $\mathrm{H}_{0}$ ditolak sedangkan bila asymp sig. $>\alpha$, maka $\mathrm{H}_{0}$ diterima, dimana taraf nyata yang digunakan $\alpha=0,05$.Berdasarkan hasil uji hipotesis pada Tabel 7 diperoleh nilai asymp sig. (2-tailed) untuk variabel Manipulasi - Akuntansi sebesar 0,038 lebih kecil dari 0,05 dengan nilai mean rank pada auditor pada KAP 31,67 dan pada akuntan pendidik 41,92, hal ini menunjukkan bahwa ada perbedaan yang signifikan persepsi responden tentang manipulasi akuntansi baik pada auditor pada KAP maupun pada akuntan pendidik.

Metode uji yang digunakan untuk menjawab permasalahan pada hipotesis 3 adalah uji Mann Whitney. Kaidah pengambilan keputusan yang digunakan dalam metode ini adalah bila asymp sig. $\leq \alpha$, maka $\mathrm{H}_{0}$ ditolak sedangkan bila asymp sig. $>\alpha$, maka $\mathrm{H}_{0}$ diterima, dimana taraf nyata yang digunakan $\alpha=0,05$. Berdasarkan hasil uji 
Putu Javani Sukma K dan I Ketut Sujana. Persepsi...

hipotesis pada Tabel 7 diperoleh nilai asymp sig. (2-tailed) untuk variabel arah manipulasi sebesar 0,038 lebih kecil dari 0.05 dengan nilai mean rank pada auditor pada KAP 31,71 dan pada akuntan pendidik 41,82, hal ini menunjukkan bahwa ada perbedaan yang signifikan persepsi responden tentang arah manipulasi baik pada auditor pada KAP maupun pada akuntan pendidik.

Metode uji yang digunakan untuk menjawab permasalahan pada hipotesis 4 adalah uji Mann Whitney. Kaidah pengambilan keputusan yang digunakan dalam metode ini adalah bila asymp sig. $\leq \alpha$, maka $\mathrm{H}_{0}$ ditolak sedangkan bila asymp sig. $>\alpha$, maka $\mathrm{H}_{0}$ diterima, dimana taraf nyata yang digunakan $\alpha=0,05$. Berdasarkan hasil uji hipotesis pada Tabel 7 diperoleh nilai asymp sig. (2-tailed) untuk variabel materialitas sebesar 0,191 lebih besar dari 0,05 dengan nilai mean rank pada auditor pada KAP 33,50 dan pada akuntan pendidik 39,42, hal ini menunjukkan bahwa tidak ada perbedaan yang signifikan persepsi responden tentang materialitas baik pada auditor pada KAP maupun pada akuntan pendidik.

Metode uji yang digunakan untuk menjwab permasalahan pada hipotesis 5 adalah uji Mann Whitney. Kaidah pengambilan keputusan yang digunakan dalam metode ini adalah bila asymp sig. $\leq \alpha$, maka $\mathrm{H}_{0}$ ditolak sedangkan bila asymp sig. $>\alpha$, maka $\mathrm{H}_{0}$ diterima, dimana taraf nyata yang digunakan $\alpha=0,05$. Berdasarkan hasil uji hipotesis pada Tabel 7 diperoleh nilai asymp sig (2-tailed) untuk variabel kecendrungan manipulasi sebesar 0,472 lebih besar dari 0,05 dengan nilai mean rank pada akuntan publik 34,52 dan pada akuntan pendidik 38,02 hal ini menunjukkan 
ISSN: 2302-8556

E-Jurnal Akuntansi Universitas Udayana

Vol.24.3.September (2018):2414-2442

bahwa tidak ada perbedaan yang signifikan persepsi responden tentang kecendrungan manipulasi baik pada auditor pada KAP maupun pada akuntan pendidik.

Berdasarkan uji hipotesis dengan menggunakan uji Mann Whitney diperoleh kesimpulan bahwa tidak terdapat perbedaan yang signifikan persepsi etis auditor pada Kantor Akuntan Publik dan akuntan pendidik pada praktik manajemen laba di tinjau dari jenis manipulasi operasional dengan nilai 0,086 lebih besar dari 0,05. Artinya, auditor pada KAP dan Akunan Pendidik memiliki prinsip yang sama yaitu selalu mengedepankan prinsip-prinsip akuntansi yang berlaku dalam mempraktikan manajemen laba ditinjau dari jenis manipulasi - operasional. Auditor pada KAP mengedepankan profesionalitas dalam melaksanakan tugasnya, dan akuntan pendidik mengajarkan kepada mahasiswa untuk mempraktikan kaidah akuntansi sesuai dengaan ketentuan yang berlaku umum.

Disamping itu dapat diketahui, bahwa antara auditor pada KAP dan akuntan pendidik mempunyai kesamaan latar belakang pendidikan. Dengan demikian dapat disimpulkan, bahwa baik auditor pada KAP maupun akuntan pendidik selalu bekerja berdasarkan etika dalam mempraktikan manajemen laba. Kesimpulan ini sesuai dengan penelitian sebelumnya, Nurmala dan Marti (2007) dalam penelitiannya menyimpulkan bahwa tidak terdapat perbedaan yang signifikan dari keempat faktor yang diteliti terhadap manajemen laba, keempat faktor tersebut adalah jenis manipulasi, arah manipulasi, materialitas dan kecenderungan. Kesimpulan ini juga tidak jauh berbeda dari penelitian yang dilakukan Clikeman et.al (2000). 
Berdasarkan uji hipotesis dengan menggunakan uji Mann Whitney diperoleh kesimpulan bahwa ada perbedaan yang signifikan persepsi responden tentang jenis manipulasi - akuntansi auditor pada KAP dan akuntan pendidik pada praktik manajemen laba di tinjau dari jenis manipulasi akuntansi dengan nilai 0,038 lebih kecil dari 0,05. Artinya, Auditor pada KAP dan akuntan pendidik memiliki persepsi yang cenderung berbeda. Akuntan pendidik lebih mengedepankan profesi dan logika dalam memahami konsep jenis manipulasi akuntansi pada praktik manajemen laba. Sedangkan auditor pada KAP mengedepankan profesionalitas dalam setiap pengambilan keputuan berdasarkan hati nurani dan etika untuk melaksanakan prinsipprinsip akuntansi yang berlaku umum. Dengan demikian dapat disimpulkan, bahwa akuntan pendidik berpegang pada propesi dan menekankan pada pemahaman akan prinsip-prinsip akuntansi yang berlaku. Sedangkan auditor pada KAP mengedepankan profesionalitas dalam setiap pengambilan keputusan didasari dengan etika dan hati nurani dalam menerapkan praktek manajemen laba. Perbedaan ini juga dapat disebakan oleh lingkungan pekerjaan, pengalam kerja dan profesionalitas. Kesimpulan ini sesuai dengan peneliti sebelumnya, Inggarwati (2010) juga mengungkapkan bahwa terdapat perbedaan persepsi etis yang nyata terhadap manajemen laba yang dilakukan melalui manipulasi keputusan operasional.

Berdasarkan uji hipotesis dengan menggunakan uji Mann Whitney diperoleh kesimpulan bahwa ada perbedaan yang signifikan persepsi etis auditor pada KAP dan akuntan pendidik pada praktik manajemen laba di tinjau dari arah manipulasi dengan nilai 0,038 lebih kecil dari 0,05. Artinya, auditor pada KAP dan akuntan pendidik 
ISSN: 2302-8556

E-Jurnal Akuntansi Universitas Udayana

Vol.24.3.September (2018):2414-2442

memiliki persepsi yang cenderung berbeda. Akuntan pendidik lebih mengedepankan profesi dalam memahami konsep manipulasi akuntansi pada praktik manajemen laba. Sedangkan auditor pada KAP mengedepankan profesionalitas dalam setiap pengambilan keputuan berdasarkan hati nurani dan etika untuk melaksanakan prinsipprinsip akuntansi yang berlaku umum.

Dapat disimpulkan, bahwa akuntan pendidik berpegang pada profesi dan menekankan pada pemahaman akan prinsip-prinsip akuntansi yang berlaku. Sedangkan auditor pada KAP mengedepankan profesionalitas dalam setiap pengambilan keputusan didasari dengan etika dan hati nurani dalam menerapkan praktek manajemen laba. Perbedaan ini juga dapat disebakan oleh lingkungan pekerjaan, pengalaman kerja dan profesionalitas. Kesimpulan ini sesuai dengan peneliti sebelumnya, Pratiwi (2011) juga mengungkapkan bahwa terdapat perbedaan persepsi etis auditor pada KAP dan akuntan pendidik di tinjau dari arah manipulasi.

Berdasarkan uji hipotesis dengan menggunakan uji Mann Whitney diperoleh kesimpulan bahwa tidak terdapat perbedaan yang signifikan persepsi etis auditor pada Kantor Akuntan Publik dan akuntan pendidik pada praktik manajemen laba di tinjau dari materialitas dengan nilai 0,191 lebih besar dari 0,05. Artinya, auditor pada KAP dan Akunan Pendidik memiliki komitmen yang sama yaitu selalu mengedepankan prinsip-prinsip akuntansi yang berlaku dalam mempraktikan manajemen laba ditinjau dari materialitas. Auditor pada KAP mengedepankan profesionalitas dalam melakasanakan tugasnya, dan akuntan pendidik mengajarkan pemahaman kepada mahasiswa untuk mempraktikan kaidah akuntansi sesuai dengaan ketentuan yang 
berlaku umum. Disamping itu dapat diketahui, bahwa antara auditor pada KAP dan akuntan pendidik mempunyai kesamaan latar belakang pendidikan.

Dengan demikian dapat dismpulkan, bahwa baik auditor pada KAP maupun akuntan pendidik selalu bekerja berdasarkan etika dalam mempraktikan manajemen laba. Kesimpulan ini sesuai dengan penelitian sebelumnya, Nurmala dan Martin (2007) dalam penelitiannya menyimpulkan bahwa tidak terdapat perbedaan yang signifikan dari keempat faktor yang diteliti terhadap manajemen laba, keempat faktor tersebut adalah jenis manipulasi, arah manipulasi, materialitas dan kecenderungan. Kesimpulan ini juga tidak jauh berbeda dari penelitian yang dilakukan Clikeman et.al (2000).

Berdasarkan uji hipotesis dengan menggunakan uji Mann Whitney diperoleh kesimpulan bahwa tidak terdapat perbedaan yang signifikan persepsi etis auditor pada Kantor Akuntan Publik dan akuntan pendidik pada praktik manajemen laba di tinjau dari kecendrungan manipulasi dengan nilai 0,472 lebih besar dari 0,05. Artinya, auditor pada KAP dan Akuntan Pendidik memiliki prinsip yang sama yaitu selalu mengedepankan prinsip-prinsip akuntansi yang berlaku dalam mempraktekan manajemen laba ditinjau dari kecenderungan manipulasi. Auditor pada KAP mengedepankan profesionalitas dalam melakasanakan tugasnya, dan akuntan pendidik mengajarkan kepada mahasiswa untuk mempraktikan kaidah akuntansi sesuai dengaan ketentuan yang berlaku umum.

Disamping itu dapat diketahui, bahwa antara auditor pada KAP dan akuntan pendidik mempunyai kesamaan latar belakang pendidikan. Dengan demikian dapat 
ISSN: 2302-8556

E-Jurnal Akuntansi Universitas Udayana

Vol.24.3.September (2018):2414-2442

disimpulkan, bahwa baik auditor pada KAP maupun akuntan pendidik selalu bekerja berdasarkan etika dalam mempraktikan manajemen laba. Kesimpuln ini sesuai dengan penelitian sebelumnya, Nurmala dan Martin (2007) dalam penelitiannya menyimpulkan bahwa tidak terdapat perbedaan yang signifikan dari keempat faktor yang diteliti terhadap manajemen laba, keempat faktor tersebut adalah jenis manipulasi, arah manipulasi, materialitas dan kecenderungan manipulasi. Kesimpulan ini juga tidak jauh berbeda dari penelitian yang dilakukan Clikeman et.al (2000).

\section{SIMPULAN}

Berdasarkan hasil penelitianmaka dapat disimpulkan bahwa tidak ada perbedaan persepsi etis auditor pada KAP dan akuntan pendidik pada praktik manajemen laba ditinjau dari jenis manipulasi operasional. Hal ini dapat diketahui karena adanya kesamaan latar belakang pendidikan.Ada perbedaan persepsi etis auditor pada KAP dan akuntan pendidik pada praktik manajemen laba ditinjau dari jenis manipulasi akuntansi.Hal ini disebabkan oleh lingkungan pekerjaan, pengalaman kerja dan profesionalitas.Ada perbedaan persepsi etis auditor pada KAP dan akuntan pendidik pada praktik manajemen laba ditinjau dari arah manipulasi.Hal ini disebabkan oleh lingkungan pekerjaan, pengalaman kerja dan profesionalitas.Tidak ada perbedaan persepsi etis audtor pada KAP dan akuntan pendidik pada praktik manajemen laba ditinjau dari materialitas.Hal ini dapat diketahui karena adanya kesamaan latar belakang pendidikan.Tidak ada perbedaan persepsi etis audtor pada KAP dan akuntan 
pendidik pada praktik manajemen laba ditinjau dari kecenderungan manipulasi. Hal ini dapat diketahui karena adanya kesamaan latar belakang pendidikan.

Berdasarkan atas simpulan diatas dan hasil analisis data, berikut ini akan dikemukakan beberapa saran yaitu Peneliti selanjutnya diharapkan memperluas atau menambah sampel penelitian misalnya auditor pemerintah yang bekerja di Badan Pemerintah Provinsi Bali atau di Indonesia, sehingga tidak hanya meneliti auditor pada KAP di Provinsi Bali dan akuntan pendidik di Fakultas Ekonomi dan Bisnis Universitas Udayana saja.Penelitian ini dapat diperluas dengan menambah variabel independen yang diduga berpengaruh kuat dalam memberikan persepsi terhadap manajemen laba.Peneliti selanjutnya diharapkan memberikan kriteria responden yang lebih spesifik. Karena di dalam penelitian ini informasi auditor yang bekerja pada KAP hanya didapat dari pegawai KAP.

\section{REFERENSI}

Agnes, Utari Widyaningdyah. 2001. Analisis factor-faktor yang berpengaruh terhadap Earnings Management pada perusahaan Go Public di Indonesia. Jurnal Akuntansi dan Keuangan. 3(2): h: 89-101.

Agoes, Sukrisno. 2004. Auditing(Pemeriksa Akuntan) oleh Kantor Akuntan Publik. Edisi 3 Jilid 1. Jakarta: Lembaga Penerbit Fakultas Ekonomi Universitas Indonesia.

Anastasia. 2005. Persepsi Manajemen Badan Usaha Milik Negara/Daerah dan Badan Usaha Milik Swasta di Jawa Timur terhadap Earning Management Audit sebagai Strategi untuk Mencegah dan Mendeteksi Kecurangan pada Fungsi Pembelian. Fakultas Ekonomi Universitas Airlangga.

Astuti, Winda., Wiwik Tiwiyanti, dan Reka Maryani. 2011. Perbedaan Persepsi Etis Mahasiswa Akuntansi yang sudah Berkerja dan yang Belum Bekerja terhadap Praktik Earnings Management. 13(2), h: 7-12. 
ISSN: 2302-8556

E-Jurnal Akuntansi Universitas Udayana Vol.24.3.September (2018):2414-2442

Ayu Purnamaningsih, Ni Ketut, dan Ariyanto, Dodik. 2016. Pengaruh Gender, Usia, Tingkat Pendidikan, dan Status Sosial Ekonomi terhadap Persepsi Etis Mahasiswa Akuntansi. 20 (2), h: 4-5. JEKT.

Bruns, W. J. Jr. dan K. A. Merchant. 1990. The Dangerous Morality of Managing Earnings. Management Accounting. Agustus, h: 22-25.

Clikeman, Paul M., Marshall A. Geiger, dan Brendan T. O’Connel. 2000. Student Perception of Earnings Management: Then Effects of National Origin and Gender. (http://www.ssrn.com).

Cressey, Donald R. 1950. Other People a Study in a Social Psycology of Embezzlement. Freepress.

Eisenhardt, K. M., R. G. Sloan, dan A. P. Sweeney. 1996. Causes and Consequences of Earning Manipulation : Analysis of Firm Subject to Enforcement Action by the SEC. Contenporary Accounting Research, 13: h: 1-36.

Fatt, James P. T., 1995. Ethics and Accountant. Journalof Business Ethics. 14(2): h: 997-1004.

Fischer, Marilyn dan Rosenzweig, Kenneth.1995. Attitudes of Student and Accounting Pratitioners Concerning the Ethical Acceptability of Earning Management. Journal of Bussines Ethics. 14(6): h: 433-444.

Ghozali, Iman. 2006. Aplikasi Analisis Multivariate dengan Program SPSS. Edisi ke 2. Semarang: Badan Penerbit Universitas Diponogoro.

Gideon, SB Boediono. 2005. Kualitas Laba: Study Pengaruh Mekanisme Corporate Governance dan Dampak Manajemen Laba dengan Menggunakan Analisis Jalur. Simposium Nasional Akuntansi VII. Solo.

Healy, P. M. 1985. The Effect of Bonus Schemes on Accounting Decision. Journal of Accounting and Economics, 7: h: 85-107.

Healy, P., dan Wahlen, J. M. 1999. A Review of The Earning Management Literature and Its Implication for Standard Setting. Accounting Horizons, 13: h: 365383.

Herawaty, Vinola. 2008. Peran Praktik Corporate Governance sebagai Moderating Variable dari Pengaruh Earnings Manajemen terhadap Nilai Perusahaan. Simposium Nasional Akuntansi 11. Pontianak.

Isnugrahadi, Indra \& Indra Wijaya Kusuma. 2009. Pengaruh Kecakapan Managerial terhadap Manajemen Laba dan Kualitas Auditor sebagai Variabel Pemoderasi. Simposium Nasional Akuntansi 12. Palembang. 
Khairunnisa. 2015. Analisis Persepsi Mahasiswa Akuntansi Universitas Bakrie terhadap Perilaku Etis Penyusunan Laporan Keuangan Perusahaan. Journal of Economic.

Malia. 2010. Skripsi Pengaruh Orientasi Etika dan Pengalaman Akuntan terhadap Persepsi Etis tentang Praktik Manajemen Laba. Hal: 105-111.

Martandi, Indiana Farid, Sri Suranta. 2006. Persepsi Akuntan, Mahasiswa Akuntansi, dan Karyawan Bagian Akuntansi dipandang dari Segi Gender terhadap Etika Bisnis dan Etika Profesi. Simposium Nasional Akuntansi IX. Agustus. 2006.

Merchant, Kenneth A., danRockness, Joanne. 1994. The Ethics of Managing Earning: An Empirical Investigation. Journal of Accounting and Public Policy, 13: h: 79-94.

Mira Diantari Sadia, Ni Putu, dan Sukartha, I Made. 2014. Pengaruh Pergantian CEO pada Praktik Manajemen Laba Perusahaan Publik yang terdaftar di Bursa Efek Indonesia. Hal: 23-28. JEKT.

Permana, Rakadhia., Eko Suyono, dan Rini Widianingsih. 2015. Analisis Persepsi Mahasiswa Fakultas Ekonomi dan Bisnis Mengenai Etika Penyusunan Laporan Keuangan. h: 46-63.

Piwi Indah Pratiwi, Ni Wayan, dan Eka Damayanthi, I Gusti Ayu. 2017. Analisis Peralatan Laba dan Faktor-faktor yang Memperngaruhinya, 20 (2). JEKT

Pratiwi, Desak K. R. K. 2011. Skripsi Persepsi Etis Akuntan Publik, Akuntan Pendidik, dan Mahasiswa Akuntansi pada Praktik Manajemen Laba. Lampiran 1, h:1-5.

Rahmawati, Suparno, Yacob., dan Qomariah, Nurul. 2006. Pengaruh Asimetri Informasi terhadap Praktik Manajemen Laba pada Perusahaan Perbankan Publik yang terdaftar di Bursa Efek Jakarta. Symposium Nasional Akuntansi IX. Padang, 23-26 Agustus.

Scott, W. R. 2000. Financial Accounting Theory. Scarborough, Ontario: Prentice Hall. Canada Inc.

Suryani, Lana. 2014. Praktik Manajemen Laba, Pertumbuhan Perusahaan, Price Earning Ratio, Audit Report Lag Terkait Penerimaan Opini Audit Going Concern. Hal: 23-24. JEKT

Yuliano, Eko. 2010. Pengaruh Mekanisme Good Corporate Governance dan Leverage Keuangan Terhadap Manajemen Laba Perusahaan Perbankan yang Terdaftar di Bursa Efek Indonesia (BEI) 2007-2008. Skrpsi. Universitas Malang. 
ISSN: 2302-8556

E-Jurnal Akuntansi Universitas Udayana

Vol.24.3.September (2018):2414-2442

_2013. Prinsip-prinsip Akuntansi Berterima Umum (PABU).http://www.pondokskripsi.wordpress.com/2013/prinsip-prinsipakuntansi-berterima-umum.html. Diakses 20 Oktober 2016. 